\author{
トコフェロールの酸化防止効果向上に \\ 関する研究（第 13 報） \\ マーガリンにおけるアミノ酸との相乗効果 \\ 青山 稔* • 丸山武紀*・兼松弘*・新谷 勛* \\ 塚本正人**.東海林茂**・松本太郎*** \\ * 財団法人日本食品油脂検查協会 (广103 東京都中央区日本橋浜町 3-27-8) \\ ** 月島食品工業株式会社 (厂134 東京都江戸川区東葛西 3-17-9) \\ *** 日本大学理工学部 (广101 東京都千代田区神田騐河台 1-8)

\section{Studies on the Improvement of the Antioxidant Effect of} \\ Tocopherols. XIII. \\ Synergistic Effect of Amino Acids on Margarine

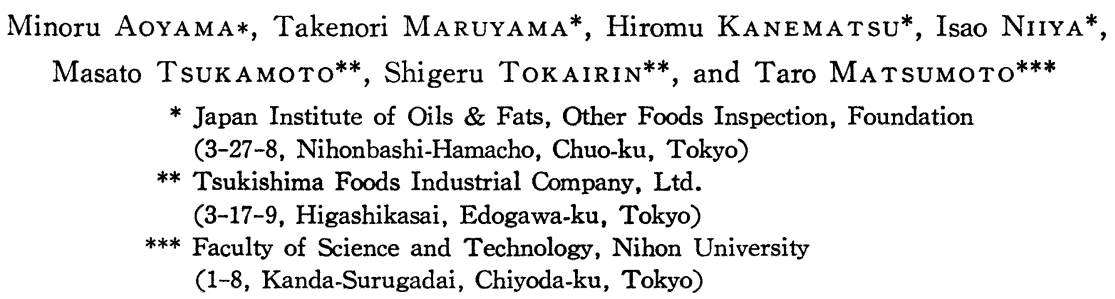

The synergistic effects of tocopherol (Toc) and 19 kinds of amino acids on the oxidative deteri= oration of emulsified fatty foods were investigated. Margarine, as an emulsified fatty food, was prepared from aqueous phase with amino acids, insoluble to fat, and lard with vitamin $A, \beta$-caroc tene and the mixture of $d$-Toc (m-Toc). Its stability toward oxidative deterioration was evaluated on the basis of change in POV and content of vitamin $\mathrm{A}$ and $\beta$-carotene during storage at $25^{\circ} \mathrm{C}$.

1) All amino acids contributed to enhance the effects of $m$-Toc on the oxidative deterioration of margarine. In particular, the addition of $\mathrm{L}$-histidine (His) along with $\mathrm{m}$-Toc caused its effect on margarine to be strongest, followed by those of L-tryptophan (Trp), L-lysine (Lys) and L-methionine (Met), whose effects were superior to that of dibutyl hydroxytoluene alone.

2) During storage at $25^{\circ} \mathrm{C}$, all amino acids showed the somewhat protective effect of Toc on oxidative decomposition in margarine, particularly the effect of His was strongest, followed by those of $\operatorname{Trp}$, Lys and L-phenylalanine.

3) During storage at $25^{\circ} \mathrm{C}$, Met was oxidized most rapidly in margarine, and could no longer be detected after 9 months. However, methionine sulfoxide, the oxidative product of Met, appeared relatively stable and served to enhance the protective effects of $\mathrm{m}$-Toc on the oxidative deterioration of margarine.

\section{1 緒}

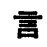

アミノ酸は油脂に不溶のため, さきにそのメチルエス テルの形でモノグリセリドを媒体とする手法により均一

前報：油化学, 36, 662 (1987)
に混和し，そしてオーブン試験及び AOM 試験でそれ らの酸化防止性及びトコフェロール（Toc）との相乘性 について報告した。これに対し，水と油の乳化系では, アミノ酸は遊離の形のまま水に溶解できるが, その酸化 防止効果及び Toc との相乗効果は乳化剂の 種類 ${ }^{2)}$ や乳 
化状態”影響されるといわれている。この点マーガリ ンは微細な水滴が油相に均一に分散した油中水型の乳化 油脂食品であり, 水相と油相の接触面積が非常に大きい ので，食塩由来の酸化促進性金属イオンの影響4) むある が油脂の酸化安定性に対するアミノ酸の効果を調べるに は適した基質とも考えられる。また，アミノ酸はタンパ ク質の構成成分なので体内に取り込まれても, また資源 的にも問題がないので, マーガリンの酸化変敗に対する Toc の効果向上に有効であれば, 実用性は高いと考えら れる。

そこで, 前報1 のオーブン試験及び $\mathrm{AOM}$ 試験の結 果に基づき, 個々のアミノ酸を Toc と併用して試作し たマーガリンの $25^{\circ} \mathrm{C}$ 保存試験によって Toc との併用 効果を比較検討した。

\section{2 実験}

\section{$2 \cdot 1$ 試料及び試薬}

マーガリンの原料油脂並びに副原料として使用した食 塩, ビタミン $\mathrm{A}$ パルミチン酸エステル, $\beta$-カロテン, デヒドロ酶酸ナトリウム, 乳化剤及び酸化防止剤の天然 濃縮 Toc (m-Toc) はいずれも前報5)と同種のものであ る。

アミノ酸は和光純薬工業（株）製のグリシン (Gly)， L-トレオニン (Thr), L-グルタミン酸 (Glu), L-メチ オニン (Met), L-トリプトファン (Trp), 及び半井化 学薬品 (株) 製の L-アスパラギン酸 (Asp), L-セリン (Ser), L-プロリン (Pro), L-アラニン (Ala), L-シス チン (Cys), L-バリン (Val), L-イソロイシン (Ile), L-ロイシン (Leu), L-チロシン (Tyr), L-フェニルア ラニン (Phe), L-リシン (Lys), L-ヒスチジン (His), L-アルギニン (Arg)，L-ヒドロキシプロリン (Hyp)の 計 19 種の試薬特級を使用した。

\section{$2 \cdot 2$ マーガリン}

マーガリンの基本的配合割合, ビタミン A 及び $\beta$ カロテンの添加量（それぞれ試料 $100 \mathrm{~g}$ 当たり 6,000 国際単位及び $0.5 \mathrm{mg}$ ）並びにその調製方法は前報らと 同じである。

マーガリンへの m-Toc 及びアミノ酸の添加量は 0.02 $\%$ 及び $100 \mathrm{ppm}$ とし, m-Toc は油相, アミノ酸は水 相に添加した。このようにして m-Toc 単独及びさらに 各アミノ酸を加えた試料並びにこれらを加えない対照試 料をそれぞれ $1 \mathrm{~kg}$ ずつ調製した。

\section{3 方 法}

マーガリン試料の酸化安定性は $25^{\circ} \mathrm{C}$ 保存試験による 過酸化物価 $(\mathrm{POV})^{6)}$, ビタミン $\mathrm{A}^{7)}$ 及び $\beta$-カロテン ${ }^{8)}$ の経時変化から評価した。

Toc は高速液体クロマトグラフィー法" ${ }^{2}$, アミノ酸は $0.05 \mathrm{~N}$ 塩酸で試料から抽出したのち高速アミノ酸分析
計法 ${ }^{100}$ にってそれぞれ経時的に分析した。

\section{3 結果及び考察}

\section{$3 \cdot 1$ マーガリンに対する m-Toc とアミノ酸の併用 効果}

$0.02 \%$ の m-Toc と $100 \mathrm{ppm}$ の各アミノ酸を併用し たマーガリンの $25^{\circ} \mathrm{C}$ 保存中における $\mathrm{POV}$ の経時変化 を Fig.-1 に示す。m-Toc 添加で POV 上昇が著しく 抑制されることは前報らのと㧍りであるが，さらにアミ ノ酸を加えるといずれも効果向上を示した。その程度を アミノ酸間で比較すると，Cys 及び Asp はわずかな向 上しか示さないが, His はもっとも大きく, Trp, Lys 及び Met もそれについで効果的であった。Trp, Lys 及び Met の Toc との併用効果が 比較的大きいことは 豚脂を用いたメチルエステルによるオーブン試験の結 果 ${ }^{1)}$ とも一致するが，そのオーブン試験 では His の場 合はあまり効果的ではなかった。しかし, 渡辺ら ${ }^{11}$ はリ ノール酸を基質とする溶液系の実験で His の Toc と の相乗効果が相当大きいと報告していることから含水系 では His の Toc との併用効果が大きくなると推察さ れる。また, オーブン試験1) ではもっとも効果的であっ たPro がマーガリンではあまり効果的でなかったこと も乳化系と非水系による相異と思われる。

ビタミン A 残存率に及ぼす各アミノ酸のI Toc との 併用効果を Table-1 に示す。ビタミン A の安定化に 対する $\mathrm{m}$-Toc の効果は各アミノ酸との併用で向上する ことを示し，その程度は Cys 及び Asp が比較的小さ

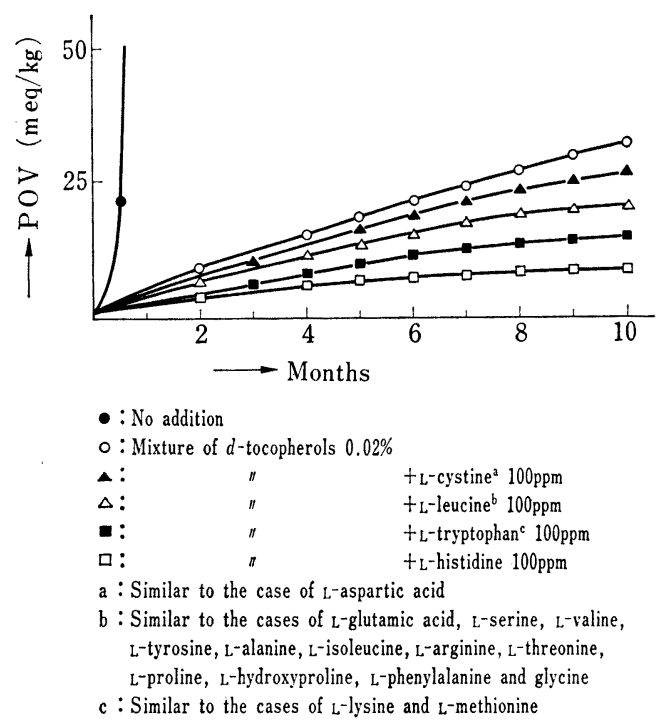

Fig.-1 Effects of amino acids along with the mixture of $d$-tocopherols on the oxi= dation of margarine during storage at $25^{\circ} \mathrm{C}$. 
Table-1 Effects of amino acids along with the mixture of $d$-tocopherols on the stability of vitamin $\mathrm{A}$ in margarine during storage at $25^{\circ} \mathrm{C}$.

\begin{tabular}{c|l|r|r|r}
\hline \multirow{2}{*}{$\begin{array}{c}\text { Mixture of } \\
\text { d-tocopherols } \\
\text { added (\%) }\end{array}$} & \multicolumn{1}{|c|}{$\begin{array}{c}\text { Amino acid added } \\
(100 \mathrm{ppm})\end{array}$} & \multicolumn{3}{|c}{ Remnant (\%) } \\
\cline { 2 - 5 } & \multicolumn{1}{|c|}{$3 \mathrm{~m}$} & $5 \mathrm{~m}$ & $7 \mathrm{~m}$ \\
\hline 0 & No addition & 16.4 & 12.1 & 6.9 \\
0.02 & No addition & 95.5 & 78.8 & 60.1 \\
0.02 & Cys, Asp & 96.1 & 83.9 & 73.3 \\
0.02 & Ile, Glu, Pro, Hyp & 96.7 & 85.4 & 77.4 \\
0.02 & Thr, Val, Arg, Ala, Gly, Ser & 97.3 & 88.2 & 81.4 \\
0.02 & Leu, Tyr & 98.0 & 90.7 & 84.1 \\
0.02 & Lys, Met, Phe, Trp & 98.5 & 92.4 & 87.3 \\
0.02 & His & 98.7 & 94.1 & 92.0 \\
\hline
\end{tabular}

Cys : L-Cystine

Asp : L-Aspartic acid

Ile : L-Isoleucine

Glu : L-Glutamic acid

Pro : L-Proline

Hyp : L-Hydroxy proline

Thr : L-Threonine

Val : L-Valine

Arg : L-Arginine

Ala : L-Alanine

Gly : Glycine

Ser : L-Serine

Leu : L-Leucine

Tyr : L-Tyrosine

Lys : L-Lysine

Met : L-Methionine

Phe : L-Phenylalanine

Trp : L-Tryptophan

His : L-Histidine

Table-2 Effects of amino acids along with the mixture of $d$-tocopherols on the stability of $\beta$-carotene in margarine during storage at $25^{\circ} \mathrm{C}$.

\begin{tabular}{c|l|c|c|c}
\hline \multirow{2}{*}{$\begin{array}{c}\text { Mixture of } \\
\begin{array}{c}\text {-tocopherols } \\
\text { added (\%) }\end{array}\end{array}$} & \multicolumn{1}{|c|}{$\begin{array}{c}\text { Amino acid added } \\
(100 \mathrm{ppm})\end{array}$} & $3 \mathrm{~m}$ & $5 \mathrm{~m}$ & $7 \mathrm{~m}$ \\
\cline { 2 - 4 } 0.02 & No addition & 50.3 & 34.0 & 22.1 \\
0.02 & Cys, Asp & 65.5 & 48.1 & 35.9 \\
0.02 & Ile, Glu, Pro & 68.4 & 54.7 & 41.9 \\
0.02 & Leu, Tyr, Thr, Val, Arg, & 77.1 & 56.4 & 47.3 \\
0.02 & Ala, Hyp, Gly & 81.4 & 66.7 & 56.0 \\
0.02 & Met, Lys, Ser, Phe & 82.7 & 68.8 & 63.9 \\
0.02 & Trp & 86.3 & 82.2 & 78.1 \\
\hline
\end{tabular}

For abbreviations see Table-1.

いのに対し, His がもっとも大きく, ついで Lys, Met, Phe 及び Trp も効果的であった。これらの結果は POV の場合とほぼ対応している。また $\beta$-カロテンの場合は Table-2 に示すようにビタミンA に比較すると残存率 は低いものの各アミノ酸による m-Toc の安定化効果の 向上傾向は類似していた。

以上の結果から，マーガリンに対する Toc の酸化防 止効果向上にもっとも有効なアミノ酸は His であり, その効果は Lーアスコルビン酸ステアリン酸エステルの 場合5)にほぼ匹敵し，合成酸化防止剤のジブチルヒドロ キシトルエン (BHT) 単独より優れている。さらに mToc の Trp, Lys 及び Met との併用も BHT に代わ る有効な酸化防止剂として利用できることがわかった。

$3 \cdot 2$ Toc 及びアミノ酸の残存率
マーガリンに添加した Toc 及び各アミノ 酸の $25^{\circ} \mathrm{C}$ 保存 5 か月後の残存率を Table3 に示寸。Toc 残存率では, m-Toc 単独の 場合は 5 か月後に $65 \%$ 残存したが，その残 存率はどのアミノ酸と併用した場合でも増加 する傾向を示した。なかでも His との併用 の場合が約 $90 \%$ と最高の残存率を示し，つ いでTrp, Lys 及び Phe の場合が 比較的高 かったのに対し, Cys, Asp 及び Glu は 80 \% 未満ともっとも低い水準であった。この 傾向は油脂, ビタミン $\mathrm{A}$ 及び $\beta$-カロテンに 対する酸化防止効果の傾向に類似しているこ とから，アミノ酸はそれ自体の酸化防止力も あるが，主として Toc を安定化することに よりその酸化防止效果を向上させると考えら れる。J. Cillard ら ${ }^{123}$ はアミ酸のキレート 化作用により $\alpha$-Toc の酸化促進性が阻止さ れると述べており，キレート化による酸化促 進性金属イオンの不活性化が Toc の安定化 の一因であ万う。一方，アミノ酸の残存率で は, Hyp が約 75\% と最高であるのに対し， Met は $17.5 \%$ ともっとも低かったが，mToc との併用効果が Met とほぼ同等の Lys は $33.8 \%$ 残存していた。また, m-Toc と の併用によるマーガリンの酸化防止効果がも っとも低いCys と，それとほぼ同等の Asp の場合もそれぞれ 41.0 及び $67.1 \%$ と相異 がみられた。しかし，アミノ酸はいずれも共 存する Toc より残存率が明らかに低いこと から，Tocより速やかに酸化されることに よっても Toc を安定化するように思われる が，その酸化安定性は Toc に対する効果と は関連がみられなかった。

$\mathrm{m}$-Toc と併用した マーガリンの酸化過程 でもっとも不安定なアミノ酸の Met について, $25^{\circ} \mathrm{C}$ 保 存中の経時変化をアミノ酸分析計で分析した結果を Fig.-2 に示す。保存期間の 経過 とともに Met は 4 か 月後までほぼ直線的に減少し, その後の減少は多少なだ らかになるが 9 か月後に消失した。これに対し, Met の 酸化生成物として認められたのはメチオニンスルホキシ ドのみであり，その含量は Met の減少傾向にほぼ対応 して増加したが， 3 か月後からその増加が鈍り 6 か月を 過ぎると逆にわずかながら減少する傾向を示した。また 両物質の合計值は初期にはほとんど変化しないが，3 月を過ぎると次第に減少する傾向を示した。名武 ${ }^{132}$ はリ ノール酸の自動酸化で添加した Met が酸化されてメチ オニンスルホキシドのみを生成すること，そしてこの酸 化生成物は Met より酸化に対して安定で，しかもわず 
Table-3 Remnant ratios of total tocopherols and individual amino acid in the margarine added them at 5 months after storage at $25^{\circ} \mathrm{C}$.

\begin{tabular}{c|l|c|c}
\hline $\begin{array}{c}\text { Mixture of } \\
\begin{array}{c}\text { d-tocopherols } \\
\text { added (\%) }\end{array}\end{array}$ & \multicolumn{1}{|c|}{$\begin{array}{c}\text { Amino acid added } \\
(100 \mathrm{ppm})\end{array}$} & \multicolumn{2}{|c}{ Remnant (\%) } \\
\cline { 2 - 4 } & T-Toc & $\begin{array}{c}\text { Amino } \\
\text { acid }\end{array}$ \\
\hline 0.02 & No addition & 65.0 & \\
0.02 & Cys & 78.5 & 41.0 \\
0.02 & Glu & 77.9 & 51.5 \\
0.02 & Asp & 79.1 & 67.1 \\
0.02 & Arg & 81.3 & 48.1 \\
0.02 & Hyp & 81.0 & 74.9 \\
0.02 & Ile, Val & 83.0 & 39.8 \\
0.02 & Pro & 82.9 & 55.1 \\
0.02 & Ala & 83.1 & 71.4 \\
0.02 & Leu, Tyr, Thr, Gly & 86.4 & 53.2 \\
0.02 & Met & 86.9 & 17.5 \\
0.02 & Ser & 87.4 & 60.7 \\
0.02 & Trp, Lys, Phe & 88.7 & 33.8 \\
0.02 & His & 90.2 & 49.3 \\
\hline
\end{tabular}

T-Toc : Total tecopherols

For other abbreviations see Table-1.

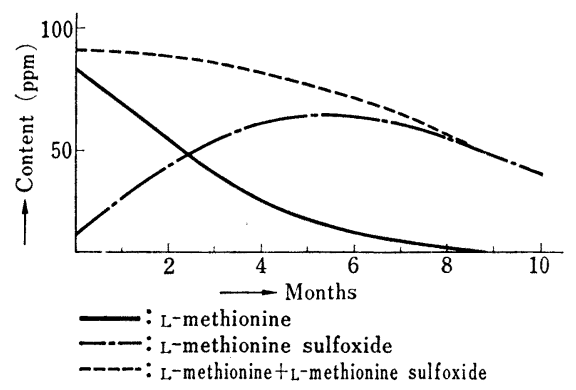

Fig.-2 Time course of oxidative deterioration of $\mathrm{L}$-methionine in the margarine added it along with the mixture of $d$-tocophe= rols during storage at $25^{\circ} \mathrm{C}$.

かながら酸化防止効果を示すことを報告している。従っ
て Metを m-Toc と併用した場合を Lys の場合と比 較すると，5 月月後の Toc の残存率では Lys のほうが やや高く, Met のほうが速やかに消失するが，生成し たメチオニンスルホキシドが m-Toc の効果向上に多少 寄与するため結果としてマーガリンに対する酸化防止効 果には差がなかったものと推察される。

なお，以上の結果は豚脂を用いて試作したマーガリン を用いて得られたもので, 前報1) オーブンでは同じアミ ノ酸でも動物性の豚脂と植物性のパーム油では異なる結

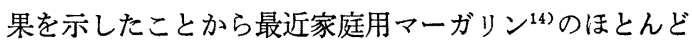
を占める高リノール型植物性マーガリンに対する效果に ついても検討する予定である。

終わりに，本報の分析に協力を得た（財）日本食品油脂検查協 会, 木下葉子, 牛草寿昭, 涻野朱美の諸君に衤锹する。

(昭和 62 年 6 月 5 日受理)

\section{文献}

1）青山 稔, 丸山武紀, 兼松 弘, 新谷 惧, 塚本正人, 東海林茂, 松本太郎, 油化学, 36, 662 (1987)

2) T. Risom, R.J. Sims, J.A. Fioriti, J. Am. Oil Chem. Soc., 57, 354 (1980)

3）湯木悦二, 石川行弘, 吉和哲朗, 油化学, 23, 714 (1974)

4) D. Gregory, Food, 6 (6), 18 (1984)

5）青山 稔, 丸山武紀, 兼松 弘, 新谷 惧, 塚本正人, 東海林茂, 松本太郎, 油化学, 35, 449 (1986)

6）日本油化学協会編, “基準油脂分析試験法”, 2.4.12-71

7) 農林省告示第 522 号（昭和 29 年 7 月 28 日）: 最終改正 農林水産省告示第 932 号 (昭和 60 年 6 月 22 日)

8) 丸山武紀, 牛草寿昭, 兼松 弘, 新谷 勛, 今村正男, 食衛誌, 18, 489 (1977)

9）兼松 弘, 牛草寿昭, 丸山武紀, 新谷 勛, 簏 大三, 豊 田 健, 川口良成, 森井健三, 渡辺 寿, 土肥由長, 町田 芳章, 石川雅夫, 松本太郎, 油化学, 31, 456 (1982)

10）日本食品工業学会食品分析法編集委員会編, “食品分析 法”, 光琳 (1982), p. 497

11）渡辺幸雄, 綾野雄幸, 栄養と食糧, 25, 621 (1972)

12) J. Cillard, P. Cillard, J. Am. Oil Chem. Soc., 63, 1165 (1986)

13）名武武昌, 栄養と食糧, 24, 63 (1971)

14）兼松 弘, 丸山武紀, 新谷 勛, 栄食誌, 37, 188 (1984) 